\title{
PLANT ENZYMES SOURCES AS PROTECTING FACTORS FOR HUMAN ORGANISM AGAINST STRESS AND ENVIRONMENTAL POLLUTANTS INDUCED DISORDERS
}

\author{
Andreea Cozea ${ }^{1}$, Stefan Manea ${ }^{1}$, Viorica Tamas ${ }^{1}$, Bordei Natalita ${ }^{1}$, Popescu Mariana ${ }^{1}$ \\ Mihaela Neagu ${ }^{1}$
}

${ }^{1}$ S.C.Hofigal Export Import SA Intrarea Serelor Street. 2 no, district 4, postal code 042124 Bucharest, Romania e-mail: andreea.cozea@yahoo.com

\begin{abstract}
Enzymes, notoriously known today for their importance in the normal functioning of the entire organism, are affected by changes of the natural environment through excessive chemisation of soil, water, air, and subsequently, food. Inadequate dietary, based mainly on industrially processed preparations have acquired more significance even in Romania, were traditional food was of high importance. As a result, in association with other factors, such as daily stress, lack of exercise, continuous rush, etc., it has led to obesity, which in turn generates serious diseases (diseases of the digestive system, diabetes, cardiovascular disease, etc.).

The authors, driven by the desire to provide new products enriched in fibers and vegetal enzymes, have studied several plants and plant organs, as potential sources of enzymes. Some of the studies relate to leafs of Aloe (Aloe vera), cabbage (Brassica oleracea), sea buckthorn (Hippophae rhamnoides), that have proven representative for the recalled purpose. The following trials have emphasized the importance of this plant material for the production of dietary supplements containing increased enzymes content, of which mainly are digestive. From the class of Hydrolases, also called 'digestive enzymes', amylase, lipase and protease were investigated. From the class of Oxidoreductases with role of neutralizing free radicals generated by the oxidative stress the most representative were revealed: SOD and catalase. The selected plants were found to hold especially high intakes of digestive enzymes that are useful in various combinations to balance the digestive system, ensuring complete and accurate digestion of food, the main way to maintain and improve health.
\end{abstract}

Keywords: environmental pollutants, enzymes, phytotherapy

\section{Introduction}

Along time, research has evidenced that our body has a limited ability to produce both digestive and of other types enzymes. Moreover, this ability decreases with aging. Digestive enzymes are proteins and they are released from the gastrointestinal system which breaks down food and absorbs nutrients. These enzymes are released by specialized cells, in the entire digestive tract, strarting from mouth, to stomach, pancreas and small intestine. Their functions are complemented by the action of gastric acid and bile secretion. Normally, the prehistoric human diet in composed of uncooked foods, rich in enzymes that aid digestion by making the digestive system to work more efficiently and save enzymes produced by the body. If the diet is low in enzymes (decreased consumption of raw foods: fruits, vegetables etc. and increased industrial processed foods), the human body is subjected to additional stress and 
discomfort may appear with different symptoms, including: indigestion, bloating, fatigue, acne, infection, difficult to heal wounds, allergies, insomnia and other.[1,2] The benefits of eating foods containing enzymes or enzyme supplements are frequently mentioned by scientists in different studies and considered of high importance. By supplementing diets with exogenous enzymes, the body is assisted in the digestion process. Subsequently, the amount of digestive enzymes that the body needs to produce is reduced, fact that is very important in the inhibition of diseases and in the aging process.

The aim of this work is to present results of investigation of several plants rich in enzymes, mainly digestive, that were further used to develop biocompatible dietary supplements of broad interest to human health.[3]

\section{Materials and Methods}

Raw material. From the multitude of studied plants, several were selected: Aloe (Aloe vera), cabbage (Brassica oleracea), seabuckthorn (Hippophae rhamnoides) leaves.[4,5,6,7]

As to conserve the enzymatic properties of the raw material, certain conditions for the plant material are to be envisaged:

1. only healthy vegetable organs, fresh, intact and not least grown in environmentally friendly conditions should be used;

Fresh plant material was processed in two ways: as juice and dry in controlled conditions material; the juice was obtained by cold pressing and depositing was done under special conditions.

2. Drying plants is one of the most important factors that can influence their quality. Plant products should be stabilized during drying by the use of controlled conditions for the reversible inactivation of the contained enzymes.[8,9]

For the dosage of the main digestive enzymes, conventional methods were used:

Determination of $\alpha$-amylase enzyme activity. Hostettler method based on hydrolysis of starch substrate under the a-amylase catalytic action in the sample, resulting compounds (maltose) whose reductive groups are determined spectrophotometrically by reaction with 3,5-dinitrosalicylic acid. [4]

Determination of lipase enzyme activity. Willstatter method based on triglyceride hydrolysis of the substrate under the action of lipase in the sample, resulting in that higher fatty acids are determined titrimetrically with a solution of $\mathrm{NaOH}$ in the presence of phenolphthalein as an indicator. [4]

Determination of enzymatic activity of protease. Drapeau method based on hydrolysis of casein in the substrate under the action of protease in the sample, resulting compounds solubles in acidic environment, that can be determined spectrophotometrically [4].

Determination of activity of cellulase enzyme. Patterson method is based on determination of the reducing groups released by the enzyme from the carboxymethylcelulose substrate with dinitrosalicylic reagent, which can be determined spectrophotometrically. [4]

Determination of the enzymatic activity of superoxide dismutase (SOD) is a method described in Winterbourne et al. Superoxide free radical catalyze the dismutation of $\mathrm{O} 2 \cdot-$ into oxygen and hydrogen peroxide. One unit of SOD is that amount of enzyme which causes $50 \%$ inhibition of the maximum inhibition by the reduction of NBT chloride. [4] 
Determination of enzymatic activity of catalase (CAT) method of Beers and Sizer. In this case, catalase-oxidoreductase substrate is represented by hydrogen peroxide undergoing a redox reaction. One section of the substrate is a donor, while the second one is an electron acceptor. This ferooxidase from the class of oxido-reductases, catalyze the decomposition of hydrogen peroxide formed by the action of other enzymes in the body, thus providing a molecular oxygen required in the body metabolic processes. [4].

\section{Results and Discussion}

Considering that the activities of enzymes from plant material change quickly in time in comparison with other parameters, enzyme determinations were performed in the first hour after obtaining the juice and prior to its stabilization with potassium sorbate. Similarly, for the dried herb, determinations were made in the first hour after drying, but also during the drying process as a control parameter. The results are presented in Table 1.

Table 1 - Values of enzyme activity of selected plant material

\begin{tabular}{|l|l|l|l|l|l|l|l|}
\hline \multirow{2}{*}{$N$} & \multicolumn{2}{|c|}{$\begin{array}{c}\text { Enzymatic } \\
\text { assays }\end{array}$} & \multicolumn{6}{|c|}{ plant material } \\
\cline { 2 - 8 } & $\begin{array}{c}\text { fresh } \\
\text { juice of } \\
\text { Aloe } \\
\text { leaves }\end{array}$ & $\begin{array}{c}\text { Aloe- } \\
\text { dried } \\
\text { leaves }\end{array}$ & $\begin{array}{c}\text { fresh } \\
\text { juice of } \\
\text { cabbage } \\
\text { leaves }\end{array}$ & $\begin{array}{c}\text { cabbage } \\
\text {-dried } \\
\text { leaves }\end{array}$ & $\begin{array}{c}\text { fresh juice of } \\
\text { seabuckthorn } \\
\text { leaves }\end{array}$ & $\begin{array}{c}\text { seabuckthorn- } \\
\text { dried leaves }\end{array}$ \\
\hline 1 & $\begin{array}{l}\text { Amylase } \\
\text { U/g/min }\end{array}$ & 24,3 & 34,0 & 15 & 27 & 35 & 38 \\
\hline 2 & $\begin{array}{l}\text { Lipase } \\
\text { U/g/min }\end{array}$ & 240,5 & 370 & 130 & 180 & 230 & 312 \\
\hline 3 & $\begin{array}{l}\text { Protease } \\
\text { U/g/min }\end{array}$ & 1,27 & 1,45 & 5,40 & 8,16 & 7,3 & 9,4 \\
\hline 4 & $\begin{array}{l}\text { Cellulase } \\
\text { U/g/min }\end{array}$ & 2,4 & 18,3 & 3,8 & 19,7 & 4,4 & 22,1 \\
\hline 5 & $\begin{array}{l}\text { Superoxid- } \\
\text { dismutase } \\
\text { EC } 50 \text { U/mg }\end{array}$ & 6738 & 4716 & 3457 & 2982 & 1740 & 1258 \\
\hline 6 & $\begin{array}{l}\text { Catalase } \\
\text { U/g/min }\end{array}$ & 169 & 232 & 174 & 249 & 134 & 155 \\
\hline
\end{tabular}

Values of enzyme activity of dried plant material are higher compared to untreated herb, due to the water loss and increased concentration in bioactive substances of interest. This reflects once again that the crucial drying conditions were respected and the enzymes' activity was not blocked, knowing that enzymes are labile under conditions of high temperature.

The highest values for amylase activity are observed for dried seabuckthorn leaves, followed by cabbage leaves, and finally by dry aloe.

The largest lipase enzymatic activity was obtained for the dried leaves, significantly decreasing for the cabbage leaves and seabuckthorn leaves.

Protease activity has the largest value in the dried leaves of seabuckthorn, followed by dried leaves of cabbage and finally by aloe.

The best Cellulase enzyme activity was found in the dried leaves of cabbage, seabuckthorn, and finally in aloe. 
As for the superoxide dismutase, high activities are observed in the fresh herb compared to the dried, respectively juices of aloe, cabbage and seabuckthorn leaves. Analysis of the catalase enzymatic activity values indicate better results for dried aloe compared to dried leaves of cabbage and dry seabuckthorn leaves.

\section{Conclusions}

For the selected vegetal material, determinations of several types of digestive enzymes were performed. Results offer a comparative view on the enzymatic content of different dried plants and juice with a possible selection of that ones that are reach in certain type of enzymes. Subsequently, new dietary supplements formulation could be developed, helpful in the disorders of the digestive system and offering essential nutrients that act synergistically, given the composition in sanogenous substances.

\section{References}

[1]. P. Sampath Kumar, Debjit Bhowmik, (2010) Aloe vera : A Potential Herb and its Medicinal Importance Journal of Chemical and Pharmaceutical Research 2(1):21-29.

[2]. Eshun K, He Q (2004). „Aloe vera: a valuable ingredient for the food, pharmaceutical and cosmetic industries--a review". Critical reviews in food science and nutrition 44 (2): 91-6.

[3]. Teleuță A., Colțun M., Mihălcescu C., Ciocîrlan N. (2008), Plante medicinale, Chișinău, editura Litera internațional,. CZU 615.322 p. 70

[4]. D. C. Cojocaru Enzimologie generala Editura: Tehnopress ISBN: 9737024516

[5]. Adrio J.L., Demain A.L. (2014) Microbial enzymes: tools for biotechnological processes. Biomolecules 4:117-139.

[6]. Fernandes P. (2010) Enzymes in food processing: a condensed overview on strategies for better biocatalysts. Enzyme Res. 2010:862537.

[7]. Vellard M.(2003) The enzyme as drug: application of enzymes as pharmaceuticals. Curr. Opin. Biotechnol. 14:444-450.

[8]. Bisswanger H. (2008) Enzyme Kinetics: Principles and Methods (Wiley-VCH, Weinheim, Germany)

[9].http://www.worthington-biochem.com/index/manual.html 